\title{
Pasienter med framskreden kreft brukte fire selvmestringsstrategier for å takle spiseproblemer
}

Illustrasjonsfoto: Colourbox.com

Hvordan takler personer med

i sine spisevaner?

Design: kvalitativ studie, fler metoder, «exploratory case study».

Setting: Storbritannia

Deltakere: Et selektert utvalg av 30 pasienter $>18$ år $(43$ til 85,53 prosent menn) som hadde framskreden kreft og fikk palliativ omsorg hjemme. Ingen fikk aktiv behandling eller parenteral- eller sondeernæring på intervjutidspunktet.

\section{METODE}

Individuelle, semistrukturerte intervjuer ble tatt opp på bån (20 til 60 minutter). Pasientene ble spurt om sine erfaringer med konsekvenser gjennom egne handendringer av matvaner og hva linger - som a forklare andre om som hadde hjulpet dem å takle sine endrede behov (individuelle endringene. Datainnsamlingen faktorer). Ett eksempel på konDek tell poirkning var antahermeneutisk fenomenologi. Data kelsen o ble analysert ved å bruke «mixed omstendigheter kun pe fre strategy for cross-case» som inklu- eksempel å ha et variert utvalg av derte innholds- og tematiske kate- mat tilgjengelig) eller hindre (for gorier.

\section{HOVEDFUNN}

Deltakerne opplevde ofte endringer i matvaner. Spising ble en plikt, og endringer i lukt, smak og struktur av mat paivirket lysten pa g evnen til ̊ spise. En foreslo genaktivitet (de som er in pasiktivet (de som er initiert av pasienten heller enn andre), som an komme fra endrede individufle og kontekstuelle faktorer. D fleste deltakerne følte de hadde no påvirkning over endrede spisevaer. Og kunne begrense negative eksempel å tilby for mye mat per måltid) egen aktivitet/mestring.

Deltakerne beskrev 141 egenaktiviteter, som alle var komponenter i fire strategier, brukt alene eller i kombinasjon, for å mestre endringer i spisevaner og assosierte negative folelser som sinne og skyld.

1. Ta kontroll. Pasienter erfarte generelt at tap av lyst og evne til å spise mat som de tidligere likte, var tap av kontroll eller konsekvens av mangel på viljestyrke. Noen handlet målrettet for å få tilbake kontroll (for eksempel à
Fysiske, sosiale og psykologisk konsekvenser av endrede matvaner påvirker livskvaliteten til pasienter med framskreden kreft (1). I sin studie beskriver Hopkins og medarbeidere hvordan endrede matvaner påvirker flere aspekter i pasientenes liv og hvilke selvmestringsstrategier som brukes for å tilpasse seg endringene. Strategiene: «ta kontroll», «fremme selvfølelser, carbeid med relasjonernog adistraksjonn gir lite foringer for pleie utover generell støttend sykepleie. Likevel, de kaster lys på det de fant foreslår Hopkins p̊a at situasjonsspesifikke tiltak og medarbeidere å støtte pasier viktig (for eksempel å tilby entens selvmestringsstrategier nteral ernæring eller støtte gjennom å tilpasse personlige geninitierte tiltak lempower- og kontekstuelle ressurser ment) innen sosiale og psykiske som en tilnærming ved endrede kontekster i pasientenes liv. matvaner. Sykepleie rettet mot å Helsepersonell har ofte konsen- støtte pasientens ressurser har trert seg om å behandle fysiske et potensiale for å øke livskvalisymptomer som er assosiert tet. Ikke bare for å bedre ernæmed ernæringsproblemer hos ringstilstand, men også for å pasienter med framskreden kreft 2). Denne tilnermingen har ofte stappunde aspekte Folatert til pasientens helse. . selvmestring for endrede matva-

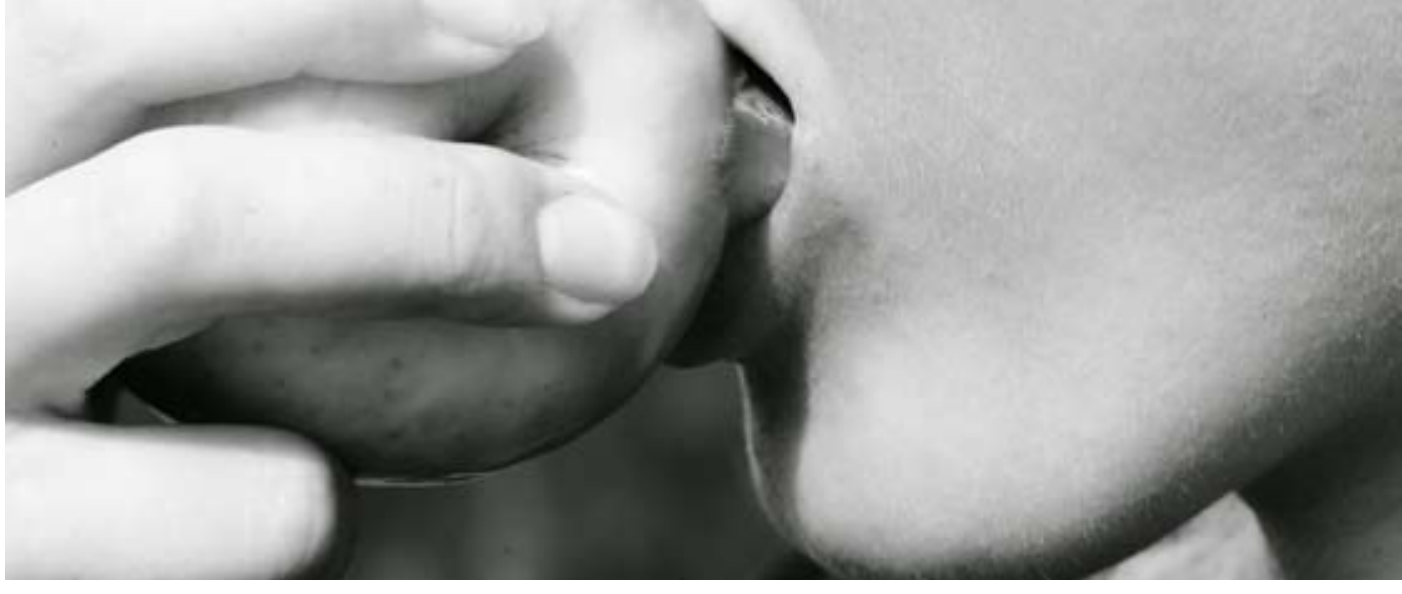

ha noe næringsrikt tilgjengelig i tilfelle de skulle føle sult).

2. Fremme selufølelse. Pasienter fornemmet mat som bra (for eksempel frukt) eller dårlig (for eksempel kake) for helse og velvære; å finne mat som både var bra og som ble tolerert kunne være vanskelig. Noen pasienter overvant følelsen av skyld eller skam for mat de ikke kunne spise, ved å fokusere po mat de hadde sist for pariste ba ig som komsencelspiste braigar som kompensajon for manglende evne til à spise idag). Eller ved a fokusere på verdien av endringer i matvaner som rammet andre familiemedlemmer (for eksempel førte til ønsket vektreduksjon hos andre).
3. Arbeid med relasioner. Endrede matvaner kunne føre til spenninger $\mathrm{i}$ familien når pasinten ikke kunne spise mat som ndre familiemedlemmer hadd laget. Dette førte ofte til skyld ho pasienten og til at pasienten bare spiste for å glede andre. Likevel, é pasient beskrev at det bedret forholdet til mannen når hun lærte ort matlaging og delte sine kokekunster med ham.

4. Distraksion. Pasienter nevnte ofte at de brukte humor som disfor dem a vacre pjorde det nulig for dem a være positive og unng tenke pa de endrede matvanene. Noen erindret og var glade for tidligere opplevelser i matveien (fo eksempel effekten av sunt kosthold ovnen til å være fysisk aktiv).

\section{USJON} selvmestringsstrategier for å takl endrede matvaner: ta kontrol fremme selvfølelse, arbeid med relasjoner og distraksjon.

Sammendrag fra: Hopkinson JB. How people with advanced cancer manag changing eating habits. J Adv Nurs

For korrespondanse: Dr JB Hopkins,

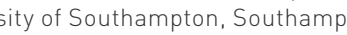
ton, UK; jbh@isoton.ac.uk. Suppor ner. Denne teorien gir et nyttig rammeverk for viktige aspekter ved selvmestring. Likevel, det er behov for å undersøke nærmere, teste og spisse teorien ved hjelp av videre forskning. I tillegg vil generering av spesifikke strategier, for å håndtere endrede matvaner som er overensstemmende med generelle strategier identifisert i denne forskningen, gi praktiske ressurser som syl
1. Marin Caro MM, Laviano A, Pichard . Impcat of nutrition on quality of life Care 2007:10:480-7.

2. Holder H. Nursing management of de $J$ in in cancer and palliative

3. Brown JK. A systematic review of the vidence on symptom management cancer-related anorexia and cachexi Oncol Nurs Forum 2002;29:517-32.

Evidence Based Nursing (EBN) vol 11 . ar 2.2008
A Fuchsia Howard RN MN University Fancouver, British Columbia, Canada 